\title{
Mata Rantai Perdagangan Lada di Kalimantan Bagian Tenggara pada Abad ke-17-18
}

\author{
Endang Susilowati \\ Departemen Sejarah, Fakultas Ilmu Budaya, Universitas Diponegoro \\ Jl. Prof. Soedarto, S.H. Tembalang, Semarang - Indonesia \\ *Alamat korespondensi: endangsusilowati@lecturer.undip.ac.id \\ DOI: https://doi.org/10.14710/jscl.v5i2.31958
}

Diterima/Received: 30 Juli 2020; Direvisi/Revised: 10 December 2020; Disetujui/Accepted: 10 December 2020

\begin{abstract}
In the period of 17th century up to 18th century, pepper was one of the important commodities of Southeastern Kalimantan. Pepper was produced by Dayak tribes in rural areas of Southeastern Kalimantan, transported through the rivers and traded in Banjarmasin, which was the most important port in the region. Merchants from all around the globe visited Banjarmasin to trade for this commodity. This article aims to study the linkage of the pepper trade in Banjarmasin which involved pepper farmers in rural areas, Chinese and Banjar merchants as the middlemen, Sultan and court officials as the holders of privileges in pepper trade, and foreign traders (Chinese, Dutch, and the British) as the buyer of pepper in the port city of Banjarmasin. By discussing the role of each part of the link, the relationship between these parts can be seen clearly. The results of this study indicate that pepper farmers are the most disadvantaged party in this trade link, they hardly benefit from the growing trade of the pepper they produced. Meanwhile the middlemen, Sultan and court officials had enjoyed huge profits. The Sultan even used pepper as a political tool to gain the support of Dutch authorities (Dutch East-India Company) in dealing with their enemies. Another important link was the Chinese, Dutch and British merchants who competed for the pepper supplies. The Chinese traders who charged the pepper for a higher price had easier way to obtain the pepper supplies than the Dutch and British traders who were supported by their trading authorities.
\end{abstract}

Keywords: Pepper Trade Chain; Economic Commodity; Maritime Trade.

\begin{abstract}
Abstrak
Pada kurun waktu abad ke-17 sampai ke-18, lada merupakan salah satu komoditas penting di Kalimantan Tenggara. Lada diproduksi oleh Suku Dayak di pedesaan Kalimantan Tenggara, diangkut melalui sungai dan diperdagangkan melalui pelabuhan terpenting di wilayah tersebut. Pedagang dari seluruh dunia mengunjungi Banjarmasin untuk berdagang komoditas ini. Tulisan ini bertujuan untuk mengkaji keterkaitan perdagangan lada di Banjarmasin yang melibatkan tiga bagian yaitu, petani, pedagang Tionghoa, dan Banjar sebagai perantara, sultan dan pejabat istana sebagai pemegang keistimewaan dalam perdagangan lada, serta pedagang asing (Cina, Belanda, dan Inggris) sebagai pembeli lada di Banjarmasin. Dengan melihat jaringan yang ada, maka hubungan antarbagian dapat terlihat dengan jelas. Hasil penelitian ini menunjukkan bahwa petani merupakan pihak yang paling dirugikan dalam mata rantai perdagangan ini. Mereka hampir tidak mendapatkan keuntungan dari perdagangan lada. Sementara para tengkulak, sultan, dan pejabat istana menikmati keuntungan besar. Sultan bahkan menggunakan lada sebagai alat politik untuk mendapatkan dukungan dari otoritas Belanda (Verenigde Oost-Indische Compagnie) dalam menghadapi musuhnya. Pedagang Cina, Belanda, dan Inggris juga bersaing untuk mendapatkan pasokan lada. Pedagang Cina mendapatkan pasokan lada dari pedagang Belanda dan Inggris serta menjual lada dengan harga lebih tinggi.
\end{abstract}

Kata Kunci: Rantai Perdagangan Lada; Komoditas Ekonomi;Perdagangan Maritim. 


\section{Pendahuluan}

Sejak permintaan rempah-rempah di pasar dunia mulai meningkat pada abad ke-16, Nusantara mulai ramai dikunjungi oleh para pedagang dari berbagai daerah dan negara. Pada waktu itu Nusantara merupakan salah satu wilayah penghasil rempah-rempah berkualitas tinggi. Pala, cengkih, kayu manis, lada, vanili, kunyit, kapulaga, dan sebagainya menjadi magnet yang mampu menyedot para pedagang dari berbagai belahan dunia untuk berbondong-bondong mengunjungi Nusantara. Rempah-rempah dan berbagai hasil hutan seperti kayu cendana, getah karet, kulit reptil, serta hasil tambang seperti emas dan timah telah mengisi lambung-lambung kapal para pedagang Eropa, Cina, Arab, India, dan lain-lain yang berlayar ke Nusantara membawa tekstil, porselen, keramik, kain sutra, obat-obatan dan sebagainya. Mereka mengangkut rempah-rempah dari berbagai daerah di Nusantara untuk diperdagangkan ke berbagai negara yang membutuhkannya. Eropa, Cina, dan Timur Tengah merupakan beberapa pasar rempah dari Nusantara. Permintaan terhadap rempah yang semakin meningkat di pasar dunia telah menyebabkan para pedagang rempah menikmati keuntungan yang sangat besar. Hal itu mendorong munculnya persaingan antarpara pedagang untuk mendapatkan lebih banyak rempah-rempah dari berbagai wilayah di Nusantara, sehingga harga rempah-rempah di berbagai daerah penghasil rempah melonjak (van Leur, 1983, p. 12). Kapal-kapal dagang Portugis, Belanda, Inggris, jung-jung Cina, dan perahuperahu dagang lokal meramaikan perairan Nusantara. Pulau-pulau penghasil rempah seperti Kepulauan Maluku, Jawa, Sumatra, Kalimantan, dan Sulawesi ramai dikunjungi baik oleh para pedagang asing maupun pedagang dari berbagai daerah di Nusantara.

Salah satu pulau penghasil rempah-rempah, khususnya lada, adalah Kalimantan. Lada (Piper Nigrum) antara lain tumbuh di wilayah Kalimantan Tenggara (Zuider-en Oosterafdeeling van Borneo) yang kini menjadi Provinsi Kalimantan Selatan. Dari sumber-sumber yang dapat dijangkau diketahui bahwa lada dari Kalimantan Tenggara mulai diperdagangkan dalam jaringan perdagangan internasional pada sekitar akhir abad ke-16 atau awal abad ke-17.
Gambaran mengenai komoditas dagang sebelum abad ke-16 seperti dituliskan dalam Hikayat Banjar tidak menyebutkan lada, melainkan kayu, rotan, damar, lilin, kayu putih, berlian, dan emas yang diangkut ke pusat perdagangan di Banjarmasin melalui transportasi sungai (Ras, 1990, p. 177). Barangkali hal itu ada kaitan dengan himbauan dari penguasa Banjar kuno agar rakyatnya hanya menanam lada untuk digunakan sendiri dan tidak untuk diperdagangkan, karena memperdagangkan lada hanya akan membawa kesengsaraan dan kehancuran negeri Banjar (Ras, 1990, p. 236). Baru setelah para pedagang Portugis, Cina, Arab, dan India menjalin hubungan dagang dengan para pedagang Banjar, Bugis, dan Jawa di Banjarmasin pada abad ke-16, kemudian juga disusul pedagang Inggris dan Belanda (Valentijn, 1862, pp. 229-230) pada dekade-dekade berikutnya, lada Banjarmasin mulai menjadi salah satu komoditas dagang yang paling dicari; meskipun jumlah produksinya masih terbilang kecil bila dibandingkan produksi lada dari Banten, Jambi, dan Palembang. Puncak kejayaan perdagangan lada di Banjarmasin terjadi pada pertengahan abad ke-17 hingga abad ke-18, sebelum akhirnya merosot pada akhir abad ke-18 seiring hilangnya perdagangan bebas lada yang biasa dilakukan oleh para pedagang lokal, sebagai akibat upaya monopoli perdagangan lada yang dilakukan oleh Belanda (Sjamsuddin, 2001, p. 4).

Dinamika dalam perdagangan lada dapat ditinjau dari berbagai aspek, namun keterbatasan sumber primer kadang membatasi sejarawan untuk dapat leluasa menuliskannya. Studi mengenai sejarah perdagangan lada di Nusantara memang sudah banyak dilakukan, baik oleh sejarawan mancanegara maupun sejarawan Indonesia. Beberapa di antaranya adalah studi yang dilakukan oleh Fong (2013), Sulanjari (1991), Andaya (1995), dan Ahyat (2014). Fong mengaitkan aktivitas perdagangan (termasuk perdagangan lada) di Banjarmasin dengan situasi Kesultanan Banjar yang sarat akan konflik antaranggota kerajaan dalam memperebutkan kepentingan politik dan ekonomi mereka pada paruh pertama abad ke-18. Situasi itu pada akhirnya mengundang masuknya kekuatan Belanda dan Inggris dengan kepentingan politik masing-masing. Sementara itu, studi Sulanjari secara periode penelitian melanjutkan studi dari Fong, namun Sulanjari menitikberatkan studinya pada situasi politik di 
Kesultanan Banjar pada paruh kedua abad ke-18 yang memang tidak dapat dilepaskan dari dinamika perdagangan lada di Banjarmasin. Senada dengan Fong dan Sulanjari, studi dari Ahyat (2014) juga mengaitkan perdagangan lada dengan Kesultanan Banjarmasin pada abad ke-17 hingga ke-18. Ia memberikan gambaran bahwa perdagangan lada di Banjarmasin telah memberikan kemakmuran pada para elite kesultanan dan keluarga mereka, sebaliknya membawa kesengsaraan pada penduduk penananam lada. Selain itu, daya tarik lada juga menyebabkan para pedagang asing, terutama Belanda dan Inggris berkontestasi untuk memperebutkan monopoli atas perdagangan lada yang menjanjikan keuntungan berlimpah. Berbeda dengan tiga karya yang telah disebutkan di depan, studi dari Andaya (1995, pp. 165-190) membahas tentang perkembangan perdagangan lada di Sumatera selama abad ke-17 dan ke-18, dan mengeksplorasi bagaimana tanaman komersial yang notabene baru tersebut mempengaruhi posisi perempuan. Sebelum menjadi tanaman perkebunan yang dikomersilkan, lada sudah dikenal sebagai tanaman rumah tangga yang pemeliharaannya banyak dilakukan oleh kaum perempuan. Ketika lada kemudian berkembang menjadi tanaman perkebunan untuk tujuan komersial, kaum perempuan tetap banyak terlibat di dalamnya, bahkan sampai pada perdagangan lada di kota pelabuhan. Studi ini sangat menarik karena menghubungkan aktivitas perdagangan lada di Sumatera dengan bergesernya peran tradisional perempuan dalam ekonomi domestik, karena adanya "budaya" laki-laki dalam perdagangan lada.

Berbeda dengan tulisan-tulisan terdahulu, artikel ini bermaksud untuk mengungkap mata rantai perdagangan lada di Kalimantan Tenggara pada abad ke-17 hingga ke-18 yang melibatkan empat pihak, yaitu orang-orang Dayak sebagai para penanam lada di pedalaman, para pedagang Banjar dan pedagang Cina lokal sebagai perantara, sultan, dan para pejabat istana sebagai pihak yang menguasai perdagangan lada di Banjarmasin, serta para pedagang mancanegara (Belanda, Inggris, Cina) sebagai pembeli lada untuk dijual di pasar dunia. Mata rantai tersebut akan dilihat melalui peran yang dimainkan oleh masing-masing pihak. Melalui berbagai pertanyaan berikut diungkapkan peranan dari bagian-bagian mata rantai tersebut. Bagaimana posisi para penanam lada dalam mata rantai perdagangan lada? Bagaimana para pedagang Banjar dan Cina menjalankan fungsinya sebagai perantara dalam perdagangan lada? Mengapa sultan dan para bangsawan Banjar kemudian terlibat dalam perdagangan lada? Bagaimana upaya para pedagang asing untuk mendapat pasokan lada di Banjarmasin?

\section{Orang Dayak: Para Penanam Lada}

Lada yang diperdagangkan di Banjarmasin sejak abad ke-16 berasal dari onderafdeeling Pulau Laut, Negara (Bakompay), Barabai, Amuntai, Kayu Tangi, dan Maluka (Fong, 2013, p. 3 \& 13; Stibbe, 1917 \& 1919, p. 372). Para penanam lada di pedalaman Kalimantan Tenggara pada umumnya adalah suku Dayak seperti Dayak Biaju, Ma'anyan, Dusun, Bukit, dan Ot Danum. Di antara suku-suku tersebut, suku Dayak Biaju atau Ngaju merupakan suku yang terbesar dan pada umumnya mereka adalah para petani lada (Sjamsuddin, 2001, pp. 4344). Mereka bermukim di kawasan berbukit dan lembah-lembah berketinggian sedang di sepanjang aliran sungai-sungai seperti di Ulu Pulau Petak, Mengkatip, Kapuas, Ulu Sampit, dan Kahayan. Sebagai petani ladang lada dan padi, suku Dayak Biaju sering berpindah pemukiman untuk menemukan lahan-lahan baru yang masih subur (Fong, 2013, p. 5) .

Perdagangan lada tidak dapat dilepaskan dari peran orang Dayak karena sebagian besar lada yang diperdagangkan di Banjarmasin berasal dari hasil ladang/ kebun orang Dayak. Di bagian selatan dan pantai timur Kalimantan, seringkali lada juga ditanam berdampingan dengan berbagai tanaman lain seperti padi, sagu, kelapa, purun, dan berbagai tanaman sayuran (Lindblad, 2012, p. 21). Pada awalnya orang Dayak menggunakan lada sebagai alat tukar untuk memenuhi kebutuhan sehari-hari. Pada musim panen atau di antara musim tanam dan panen, mayoritas petani lada memenuhi kebutuhan hidup dengan menukarkan lada dan hasil hutan lainnya dengan garam, beras, kapas, manik-manik, tembakau, dan kebutuhan seharihari lainnya yang dibawa oleh para pedagang Banjar, Bugis, Jawa, dan Cina ke pedalaman. Seiring dengan perkembangan pusat-pusat 
perdagangan di Kalimantan Tenggara, permintaan terhadap hasil hutan dan hasil pertanian juga semakin meningkat. Situasi itu tidak jarang memosisikan para kepala suku Dayak sebagai agen perdagangan desa atau sebagai pedagang "ekspor" utama untuk wilayah mereka (Peluso, 1989, p. 8) dan menghubungkan dusun-dusun penghasil lada di pedalaman dengan pusat-pusat pengumpulan lada dan hasil hutan lainnya di muara-muara sungai.

Wilayah pemukiman suku Dayak Biaju berada di bawah kekuasaan Kerajaan Banjarmasin, oleh karena itu mereka diwajibkan membayar pajak kepada Sultan. Pajak yang harus dibayar oleh orang-orang Dayak di pedalaman terdiri dari dua jenis, yaitu hasil dan serah. Hasilmerupakan pajak tahunan dalam bentuk emas senilai $5 \%$ dari jumlah total produksi lahan yang digarap, sedangkan serah merupakan pajak in natura, terutama lada (Fong, 2013, p. 6). Tampaknya pajak yang harus dibayar oleh orang Biaju cukup memberatkan, sehingga ada upaya untuk menghindari pembayaran pajak dan penyerahan wajib hasil lada. Tidak jarang orang Dayak Biaju melakukan protes atau membangkang untuk menyerahkan hasil lada kepada sultan pada setiap musim panen lada. Untuk itu mereka dianggap memberontak dan bisa ditangkap untuk dijadikan budak di rumah-rumah penguasa lokal (Fong, 2013, p. 8).

Permintaan lada yang terus meningkat menyebabkan semakin banyak tanah di Hulu Sungai, perbukitan di atas Martapura, dan wilayah Tanah Laut dipenuhi tanaman lada (Potter, 2000, p. 375). Suku Dayak Biaju menjadi tumpuan penyedia lada. Pada musim panen lada yang berlangsung mulai bulan September dan berakhir pada bulan Maret, produksi lada suku Biaju di Kahayan dan Negara cukup melimpah. Di luar masa panen itu bahkan pedagang kadang masih bisa memperoleh lada dalam jumlah kecil di desadesa Biaju. Namun, sebagai produsen lada, orang Biaju tidak mempunyai kewenangan untuk menentukan sendiri harga ladanya, karena hak untuk menentukan harga lada berada di tangan otoritas Kesultanan Banjar. Seringkali otoritas Banjar memberi harga rendah pada hasil lada orang Biaju, sehingga menyebabkan kerugian pada para penanam lada ini (Fong, 2013, p. 173). Sebagai salah satu bagian dari mata rantai perdagangan lada, peran para penanam lada ini sangat penting.
Tanpa kerja keras mereka, lada tidak akan tersedia di pusat dagang Banjarmasin. Meskipun demikian, dalam mata rantai peragangan lada, orang Dayak menjadi pihak yang paling lemah dan tidak memiliki daya tawar. Dari kaca mata otoritas kesultanan Banjar, orang Dayak penanam lada diposisikan sebagai "rakyat" yang harus tunduk dan mematuhi semua ketentuan dari pusat kekuasaan. Dari kaca mata para pedagang perantara (Banjar dan Cina) orang Dayak dipandang sebagai "pasar" bagi barang dagangan mereka. Barang-barang dagangan seperti beras, garam, tembakau, bahan pakaian, dan manik-manik akan ditukar dengan lada yang bernilai tinggi. Gambaran mengenai jumlah produksi lada yang dihasilkan oleh para penanam lada dan diperdagangkan di Banjarmasin hanya diperoleh dari sumber yang sangat terbatas, sebagaimana tertera pada Gambar 1.

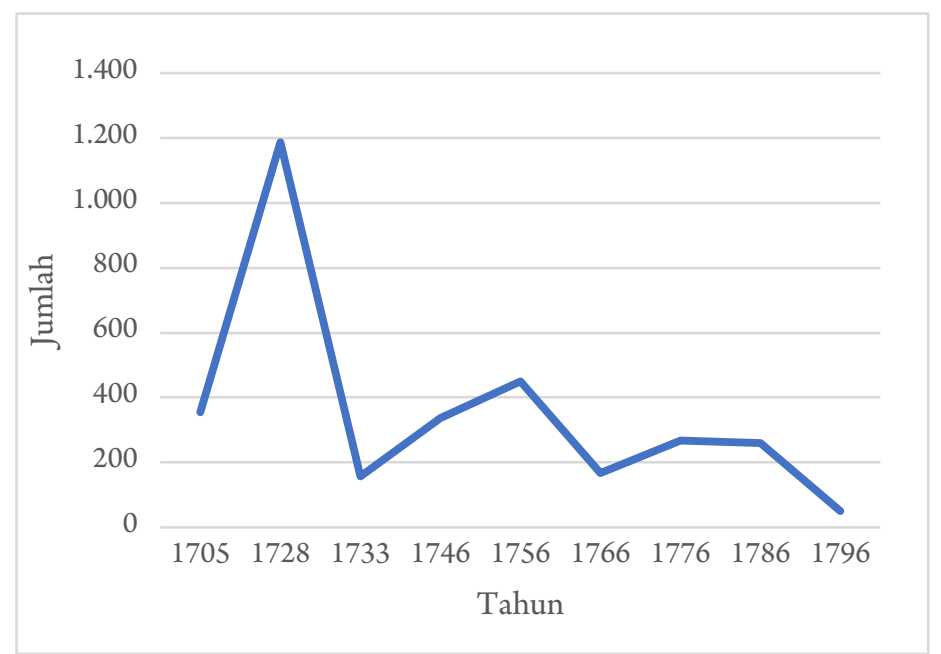

Gambar 1. Prakiraan Jumlah Produksi Lada dari Banjarmasin pada Abad ke-18.

Sumber: (Stibbe, 1917 \& 1919; Noorlander, 1935; Fong, 2013).

\section{Para Pedagang Perantara}

Lada dari pedalaman Kalimantan Tenggara mengalir menyusuri sungai, dari hulu menuju hilir, memenuhi perahu-perahu para pedagang Banjar yang memiliki "hak istimewa" sebagai pengumpul lada dari dusun-dusun Dayak dan para pedagang Cina yang sudah lama menetap di Banjarmasin. Mereka adalah mata rantai kedua dalam perdagangan lada di wilayah ini. Para pedagang Banjar mempunyai kemampuan untuk berhubungan langsung dengan orang-orang Dayak penghasil lada. Mereka juga dapat memahami 
"transaksi bisu"dengan orang Dayak (Lindblad, 2012, p. 12). Pada awal transaksi dengan pedagang Banjar, orang Dayak melakukannya tanpa bertatap muka. Konon mereka mempunyai sifat pemalu, sehingga dalam bertransaksi mereka hanya meletakkan lada, hasil hutan, atau hasil bumi mereka di suatu tempat dan mereka mengawasinya dari tempat tersembunyi. Barang-barang itu kemudian ditukar dengan barang kebutuhan sehari-hari yang dibawa oleh para pedagang. Keesokan harinya orang-orang Dayak akan datang ke tempat barang diletakkan dan menemukan bahwa barang-barang yang mereka butuhkan sudah ada di sana.

Pada musim panen lada, para pedagang lokal (terutama pedagang Banjar) berlayar ke arah hulu sungai, mendatangi dusun-dusun penghasil lada di pedalaman. Mereka berlayar menyusuri sungaisungai hingga jauh ke pedalaman yang kadang hanya dapat dilayari perahu kecil atau rakit sehingga membutuhkan waktu tempuh yang cukup lama. Para pedagang ini sudah biasa bertransaksi dengan orang-orang Dayak dan mengembangkan perdagangan sungai. Selain pedagang Banjar, pedagang Cina lokal juga melakukan perdagangan sungai, tetapi untuk pengiriman jarak jauh karena mereka menguasai pasar bahan pokok regional di Banjarmasin dan jalur perdagangan ke Singapura. Oleh karena itu, tidak jarang terjadi tumpang tindih kepentingan antara pedagang Banjar dan pedagang Cina dalam perdagangan sungai (Lindblad, 2012, p. 13).

Di dalam mata rantai perdagangan lada di Banjarmasin, pedagang Banjar dan Cina berperan sebagai pedagang perantara baik bagi para pedagang Eropa maupun para pedagang Nusantara, terutama Bugis dan Jawa. Namun pedagang Cina juga membeli lada untuk diangkut langsung ke Singapura atau ke Cina. Sebelum masuknya para pedagang Eropa, lada diangkut dari pelabuhan Banjarmasin ke pelabuhan Batavia, Banten, atau pelabuhan-pelabuhan di Selat Malaka untuk kemudian dikapalkan ke pasar dunia bersama dengan lada dari berbagai daerah lain di Nusantara. Para pedagang Nusantara pada umumnya mengangkut lada dalam perdagangan antarpulau, tetapi pada puncak perdagangan lada, kapal-kapal pedagang Banjar bahkan mengangkut lada dari Banjarmasin langsung ke Cochin Cina (Potter, 2000, p. 376).

Kedatangan para pedagang dari luar pulau, seperti Bugis dan Jawa, ke Banjarmasin dan kontakkontak yang terjalin antara para pedagang pendatang tersebut dengan penduduk penanam dan pedagang lokal telah mendorong terjadinya pertukaran lada dan hasil produksi lainnya dari pedalaman dengan barang-barang yang dibawa oleh para pedagang dari luar. Ada kalanya lada juga dijual kepada pedagang pendatang demi menjaga hubungan baik dengan mereka (Noorlander, 1935, p. 4).

Pedagang Bugis sudah sejak abad ke-17 menetap di pantai Timur Kalimantan dan mengendalikan perdagangan di sana. Pedagang Bugis juga melakukan transaksi dengan orang Dayak melalui para kepala suku Dayak untuk sarang burung dan kulit reptil, sementara itu untuk lada mereka bertransaksi dengan pedagang Banjar atau Cina. Berbeda dengan para pedagang Banjar dan Cina yang dominan dalam perdagangan sungai dengan penduduk di pedalaman, para pedagang Bugis lebih berkonsentrasi pada perdagangan ke luar atau antarpulau (Atsushi, 2010, p. 81). Dengan cara ini, lada dari dusun-dusun Dayak di pedalaman Kalimantan diangkut ke berbagai kota pelabuhan di Nusantara hingga ke pasar dunia.

\section{Peranan Sultan dalam Perdagangan Lada}

Kalimantan Tenggara dengan pusat perdagangan di Banjarmasin mulai muncul sebagai pasar antara dalam perdagangan rempah-rempah setelah Mataram menghancurkan kota dagang Gresik di Jawa Timur pada pertengahan abad ke-17. Pada waktu itu, pusat perdagangan rempah-rempah perlahan-lahan bergeser ke Makassar. Jalur perdagangan bukan lagi dari Maluku melalui Gresik menuju Selat Malaka, tetapi dari Maluku melalui Makassar dan Kalimantan Tenggara menuju Selat Malaka atau Banten (Schrieke, 1955, p. 72). Kehadiran jung-jung Cina dan kapal-kapal layar Eropa telah membuat pelabuhan Banjarmasin semakin ramai, sehingga penghasilan dari pajakpajak di pelabuhan juga meningkat. Perdagangan ladapun mulai tumbuh, semakin berkembang dan menjadi mapan, apalagi setelah para pedagang pantai utara Jawa memindahkan aktivitas mereka 
ke Banjarmasin karena Surabaya dikuasai Mataram dan menjadi tidak aman bagi aktivitas perdagangan (Potter, 2000, p. 375).

Ketika permintaan lada terus mengalir dan perdagangan lada mulai mapan pada abad ke-17, sultan dan para bangsawan Banjar banyak terlibat di dalamnya. Sebagai salah satu bagian dari mata rantai dalam perdagangan lada, mereka menempati posisi paling dominan. Mereka membeli lada dari para pedagang perantara yang mendapatkannya langsung dari para penanam di pedalaman. Sultan juga berhak menentukan sendiri harga lada yang dibeli dari para penanam atau para pedagang perantara. Dalam hal ini sultan akan memberi harga rendah ketika membeli dari penanam lada atau pedagang perantara dan menjualnya kepada para pedagang Eropa dengan harga beberapa kali lipat dari harga belinya. Pada pertengahan abad ke18 misalnya, ketika perdagangan lada masih sangat ramai, sultan membayar lada dari para penanam lada hanya 1 real Spanyol per pikul (sekitar 62,5 $\mathrm{kg}$ ). Lada kemudian dijual kepada pedagang Belanda seharga 3 real Spanyol per pikul dan 4 real Spanyol per pikul kepada pedagang Inggris (Sulanjari, 1991, p. 67).

Ekspor lada juga harus seizin sultan karena Sultan Banjar adalah pemegang hak monopoli atas perdagangan lada. Transaksi-transaksi dagang antara otoritas kesultanan Banjar dengan para pedagang Eropa tentu tidak pernah meminta pertimbangan para penanam lada maupun para pedagang. Dengan demikian, sultan dan keluarga bangsawan menjadi pihak yang paling banyak mengambil keuntungan dari perdagangan lada. Pada waktu itu, lada menjadi salah satu sumber pendapatan penting bagi kerajaan, sultan, serta para bangsawan, dan keluarga mereka. Keuntungan ekonomi yang timbul dari perdagangan lada itu membuat sultan dan para bangsawan hidup bergelimang harta (Ahyat, 2014, p. 1493).

Sebagai ujung tombak dalam mata rantai perdagangan lada, Sultan tidak hanya mendapatkan keuntungan ekonomi saja, melainkan juga keuntungan politik. Lada menyebabkan bangsa Eropa, terutama Belanda dan Inggris, silih berganti mengunjungi Banjarmasin dan berusaha menanamkan pengaruhnya di wilayah kesultanan. Sultan menggunakan lada sebagai alat untuk mendapatkan dukungan atau bantuan dari kekuatan asing apabila dibutuhkan. Sebaliknya, penguasa Belanda atau Inggris juga menjadikan lada sebagai alat untuk mendapatkan keuntungan ekonomi dan kemudian juga keuntungan politik.

\section{Pedagang Asing dalam Mata Rantai Perdagangan Lada}

Pertumbuhan produksi dan perkembangan perdagangan lada telah mampu mengubah Banjarmasin menjadi pasar lada yang diperhitungkan di Asia Tenggara pada awal abad ke-17. Hal itu tidak terlepas dari kehadiran para pedagang asing seperti pedagang Cina, Belanda, dan Inggris yang tidak pernah berhenti berusaha untuk mendapatkan pasokan lada terbanyak dari Banjarmasin. Dalam mata rantai ini, pedagang Cina sebagai pembeli lada lebih mudah mendapat pasokan lada dari para pedagang perantara maupun dari otoritas Kesultanan Banjar, sehingga mereka dapat berlayar kembali ke negeri mereka dengan jung-jung penuh lada. Para pedagang perantara dan keluarga bangsawan terbukti lebih senang menjual lada mereka kepada para pedagang Cina karena yang disebut terakhir ini bersedia memberi harga lebih tinggi untuk lada mereka, dibanding harga yang diberikan oleh pedagang Inggris dan Belanda.

Dalam upaya untuk mendapatkan pasokan lada sebanyak-banyaknya dan mengeliminasi persaingan dengan para pedagang lain, terutama pedagang Cina yang merupakan saingan terberat, pedagang Belanda berusaha untuk memperoleh hak istimewa dalam pembelian lada di Banjarmasin. Upaya itu telah dimulai sejak awal abad ke-17 meskipun belum membawa hasil seperti diharapkan. Sultan Banjar dan para bangsawan yang menguasai perdagangan lada tidak begitu saja percaya pada para pedagang asing yang dianggap dapat mengancam perdagangan bebas yang telah berlangsung sejak lama. Tidak mudah bagi pedagang Eropa untuk dapat menguasai perdagangan lada di Banjarmasin. Hal itu terbukti dengan terjadinya beberapa peristiwa pembunuhan terhadap pedagang Belanda atau utusan otoritas Belanda di Batavia yang berusaha untuk menguasai perdagangan lada di Banjarmasin. Pembunuhan terhadap Gillis Michielszoon, seorang pedagang utusan perusahaan Belanda pada 1607 merupakan salah 
satu contohnya (Noorlander, 1935, p. 5; Lindblad, 2012, p. 8; Fong, 2013, p. 25). Peristiwa ini berakibat dibakarnya pusat pemerintahan di Banjarmasin oleh Belanda pada 1612, sehingga harus dibangun pusat pemerintahan baru di Kayu Tangi dan pusat kota di dekat Kota Martapura (Saleh, t.t., p. 43).

Upaya Belanda yang terus-menerus dilakukan untuk memperoleh persetujuan sultan dalam perdagangan lada terwujud pada 1635 . Berkat bantuan seorang syahbandar di Banjarmasin, sebuah kontrak pembelian lada dibuat antara otoritas Vereenigde Oos-Indische Compagnie (VOC) dengan Kesultanan Banjar. Di dalam kontrak tersebut tercantum bahwa Sultan Banjar hanya akan menjual lada hasil panen pertama pada bulan September dan Oktober kepada VOC dengan harga 5 real per pikul dan VOC akan membantu mengembalikan kekuasaan Sultan Banjar atas wilayah Pasir dan Kutai (Poelinggomang, 2002, pp. 38-39). Pada waktu itu VOC dijanjikan akan mendapatkan 600 pikul lada seharga 3000 real Spanyol (Arsip Nasional Republik Indonesia, 1965, pp. 2-3). VOC juga diizinkan mendirikan loji dan membuka usaha dagang di Banjarmasin. Kontrak-kontrak serupa juga berulang kali dibuat dengan pedagang Inggris.

Dalam waktu yang bersamaan, Sultan Banjar juga memberi izin pembelian lada kepada pedagang Inggris yang mendapat bantuan dari salah seorang bangsawan kaya di Kesultanan Banjar, yaitu Raja Itam. Pihak Belanda melayangkan protes kepada sultan, tetapi sultan berkilah dengan meyakinkan pihak Belanda bahwa Inggris tidak akan memperoleh lada. Untuk mencegah penjualan lada kepada Inggris, VOC segera melaksanakan ekspedisi ke Pasir dan Kutai yang telah mengabaikan kekuasaan Sultan Banjar. Dalam ekspedisi tersebut Pasir menolak untuk menyerah sehingga diserang VOC, sedangkan Kutai bersedia mengakui kekuasaan Kerajaan Banjar. Hasil ekspedisi VOC tersebut membuat Sultan senang sehingga kontrak perdagangan lada dengan VOC tetap dipertahankan (Noorlander, 1935, p. 7). Namun, pada 1637 hubungan Belanda dan Sultan Banjar memburuk, sehingga tidak ada lada yang diperoleh Belanda. Sementara itu, pada 1669 Inggris berhasil memperoleh pasokan lada sebanyak 150 ton dengan harga satu real Spanyol per 13 gantang (Fong, 2013, p. 46).

Otoritas Belanda dan Inggris selalu berusaha untuk membuat berbagai kontrak dengan Kesultanan Banjar agar mendapatkan monopoli dalam perdagangan lada. Namun, kontrak-kontrak tersebut kadang diakhiri dengan pembakaran loji, kapal, atau harta milik orang-orang Eropa. Pembunuhan-pembunuhan terhadap para pedagang atau utusan Belanda dan Inggris pada 1638, 1694, dan 1707 misalnya, menggambarkan ketidakrelaan para penguasa Banjar memberi peluang kepada orang-orang Eropa untuk menguasai perdagangan lada (Saleh, t. t., p. 57). Tampaknya Sultan Banjar berusaha untuk mempertahankan perdagangan bebas yang lebih menguntungkan seperti pada masa-masa sebelumnya. Selain itu, adanya keinginan yang kuat dari sultan dan rakyat Banjar untuk tidak jatuh dalam kekuasaan bangsa asing menyebabkan para pedagang Eropa sulit untuk mendapatkan hak monopoli dalam perdagangan lada di Banjarmasin. Oleh karena itu, hingga pertengahan abad ke-18 sebenarnya tidak ada pedagang asing, sebagai mata rantai terluar dalam perdagangan lada, yang memperoleh kesempatan untuk menetapkan dan menjalankan usaha dagang dengan tenang di Banjarmasin (Noorlander, 1935, p. 5).

\section{Simpulan}

Lada merupakan salah satu jenis rempah-rempah yang penggunaannya paling banyak di dunia dibandingkan dengan cengkih, pala, dan kayu manis. Lada memiliki banyak manfaat bagi manusia. Selain dapat digunakan sebagai bumbu dalam berbagai masakan, lada juga dapat digunakan sebagai bahan obat. Sejak berabad-abad yang lalu lada telah dikirim ke berbagai negara guna memenuhi kebutuhan di pasar dunia yang terus meningkat. Para pedagang dari berbagai bangsa telah menikmati keuntungan besar dari perdagangan lada.

Geliat perdagangan telah membentuk sebuah mata rantai. Perdagangan lada tidak hanya melibatkan para pedagang (lokal maupun asing), melainkan juga menggerakkan sebagian besar penanam lada hingga sultan dan keluarga bangsawan untuk terlibat di dalamnya. Para 
penanam lada sebagai "rakyat" harus mengikuti kehendak "tuan"nya, yaitu otoritas kesultanan dan para pemimpin lokal, sehingga tidak jarang terjadi pemaksaan untuk menanam lada seiring dengan semakin meningkatnya permintaan pasar. Pihak yang banyak menikmati keuntungan, selain otoritas kesultanan dan para pejabat istana beserta keluarga mereka, tentu adalah para pedagang lada, baik para pedagang lokal maupun para pedagang asing.

Kalimantan Tenggara pernah menjadi salah satu sentra lada yang penting di Nusantara, meskipun keterlibatannya dalam perdagangan lada terbilang paling akhir dibandingkan dengan Sumatera, Jawa, Maluku, dan Sulawesi. Namun, semua itu kini tinggal kenangan. Kebun-kebun lada telah berubah menjadi kebun karet dan kelapa sawit. Sulur-sulur penuh buah ladapun sudah tidak terlihat lagi bekasnya.

\section{Referensi}

Ahyat, I. S. (2014). Pepper trade and the sultanate of Banjarmasin in the $17^{\text {th }}-18^{\text {th }}$ century. International Journal of Science and Research, 3 (8), 1491-1496.

Andaya, B. W. (1995). The pepper trade in premodern southeast asia. Journal of the Economic and Social History of the Orient, 38 (2), 165-190. https://doi.org/10.1163/15685209526005 79

Arsip Nasional Republik Indonesia (ANRI). (1965). Surat-surat perjanjian antara Kesultanan Banjarmasin dengan pemerintahan-pemerintahan VOC, Bataafse Republiek, Inggris, dan HindiaBelanda 1635-1860. Djakarta: ANRI.

Atsushi, O. (2010). Pirates or entrepreneurs? The migration and trade of sea people in outhwest Kalimantan, c. 1770-1820. Indonesia, 90, pp. 67-95. Retrieved from https://www.jstor.org/stable/20798233.

Stibbe, D.G. (1917\&1919). Encyclopaedie van

Nederlandsch-Indie. Derde jaargang. 'sGravenhage: Martijnus Nijhoff.

Fong, G. Y. (2013). Perdagangan dan politik Banjarmasin 1700-1747. Yogyakarta: Lilin Persada Press.
Lindblad, J. T. (2012). Antara Dayak dan Belanda: Sejarah ekonomi Kalimantan Timur dan Kalimantan Selatan 1880-1942. Jakarta/Malang: KITLV/Lilin Persada Press.

Noorlander, J. C. (1935). Banjarmasin en de Compagnie in de tweede helft der $18^{\text {de eeuw }}$ (Ph. D dissertation, Univeritas Leiden).

Peluso, N. L. (1987). Merchants, manipulation, and minor forest products on the Mahakam: Bugis political-economic strategies in pre-colonial Kutai. International Workshop: Trade, Society, and Belief in South Sulawesi and its Maritime World. Leiden, 2-6 November.

Poelinggomang, E. L. (2002). Makassar abad XIX: Studi tentang kebijakan perdagangan maritim. Jakarta: Kepustakaan Populer Gramedia.

Potter, L. (2000). Orang Banjar di dan di luar hulu sungai, Kalimantan Selatan: Studi tentang kemandirian budaya, peluang ekonomi, dan mobilitas. In J. T. Lindblad (Eds.), Sejarah ekonomi modern Indonesia: Berbagai tantangan baru. Jakarta: LP3ES.

Ras, J. J. (1990). Hikayat Banjar (Siti Hawa Salleh, Terj.). Kuala Lumpur: Dewan Bahasa dan Pustaka Kementerian Pendidikan Malaysia.

Saleh, M. I. (tanpa tahun). Bandjarmasin. Bandung: K.P.P.K Balai Pendidikan Guru.

Schrieke, B. (1955). Indonesian sociological studies, part one. The Hague/Bandung: N.V. Uitgeverij W. van Hoeve.

Sjamsuddin, H. (2001). Pegustian dan Temenggung. Akar Sosial, Politik, Etnis, dan Dinasti. Jakarta: Balai Pustaka.

Sulanjari (1991). Politik dan perdagangan lada di kesultanan Banjarmasin 1717-1787. (Tesis), Universitas Indonesia.

Valentijn, F. (1862). Oud en Nieuw Oost-Indien. Amsterdam: Wed. J.C. van Kesteren \& Zoon.

van Leur, J. C. (1983). Indonesian trade and society. Essays in Asian social and economic history. Dordrecht: Foris Publications Holland. 